\title{
A ESCRITA DA AUSÊNCIA EM A CHAVE DE CASA: PERFORMATIVIDADE DA VOZ NARRATIVA
}

Paulo Alberto da Silva Sales

Resumo: Desenvolve-se uma leitura do romance $A$ chave de casa (2007), de Tatiana Salem Levy, no intuito de evidenciar como a voz autodiegética - ao adotar tanto a focalização interna fixa quanto a variável e a múltipla - articula ausências de escrita, seja no nível estrutural (por meio da fragmentação, digressão, metaficção) e/ ou no entrelaçamento dos eixos narrativos que compõem o enredo. Por se tratar de uma autoficção, a diegese de Levy difere-se de uma autobiografia e de um romance autobiográfico por apresentar uma escrita performática e ambígua que coloca em xeque os limites de representação do eu ao forjar elementos autobiográficos. Além disso, a narradora-protagonista se apresenta de forma desterritorializada, multi-identitária e fortemente vinculada aos aspectos "estritamente reais" de Tatiana Salem Levy. Tais biografemas são arquitetados por uma linguagem especular que pulsa no desejo de revelar a verdade textual. Para tanto, nos valemos dos estudos de Barthes (1999; 2004; 2010), Blanchot (1987; 1997; 2013), Deleuze (2010a; 2010b; 2011), Doubrovsky (1977), Faedrich (2014; 2016), Figueiredo (2013), Foucault (2006; 2010), Gasparini (2008; 2016), Hall (2006), Hutcheon (1984), Klinger (2008; 2012), Lejeune (2014), dentre outros. Dando cabo à leitura, constatamos que as diferentes formas fragmentárias presentes nos eixos do romance convergem entre si no propósito de construir, como quer a instância narrativa, a (ir)realidade fictícia.

Palavras-chave: Tatiana Salem Levy; Ausência; Voz narrativa.

Abstract: It is developed a reading of the novel $A$ chave de casa (2007), by Tatiana Salem Levy in order to verify how the autodigetic voice - by adopting the intern fix focalization as much as variable and multiple - articulates writing absences in narrative structural level (by fragmentation, digression, metafiction) in/or intertwining to the four narrative axes that make up the plot. Because it is an autofiction the Levy's text is different from autobiography and the autobiographic novel in view of itself because it presents a performative and ambiguous writing that contests the limits representation of self by the fact to 
forge the autobiographical elements. Besides the narrative voice shows itself in the plot by deterritorialized, multi-identity and strongly linked to Tatiana Salem Levy real aspects who once incorporated in the fiction transforms into a speculate language that desires to reveal the text truth. For that, we based on the studies of Blanchot $(1987 ; 1997 ; 2013)$, Deleuze (2010a; 2010b), Doubrovsky (1977), Faedrich (2014; 2016), Figueiredo (2013), Foucault (2006; 2010), Gasparini (2008; 2016), Hall (2006), Hutcheon (1984), Klinger (2008; 2012), Lejeune (2014), among others. At the end we evidence that the different fragmentary ways in novel's axes converge each other to make, according to the narrative instance, the unreality fiction.

Keywords: Tatiana Salem Levy; Absence; Narrative voice.

\section{AUTOFICÇÃO: A ESCRITA PERFORMÁTICA DO EU}

Em 1977, o crítico, escritor e teórico francês Serge Doubrovsky publicou seu livro Fils, intitulado por ele próprio como uma autoficção. Tal narrativa é constituída por uma mistura heterogênea, fragmentada e na qual há um jogo textual de referências autorais diversas. Em tais hibridismos, cria-se a autoficção, gênero que trabalha com o esmaecimento das fronteiras entre real e ficcional, muito embora o texto apresente um "desejo" biográfico. Por meio de uma escrita que "emprega o presente da narração" em uma diegese que tem "a pulsão de 'se revelar em sua verdade" (GASPARINI, 2008, p. 209), a escrita autofictícia proporciona ao romancista meios de articular, textualmente, fragmentos autobiográficos e memorialísticos por meio de uma aventura no/pelo 
universo romanesco. Interessante destacar, desde já, que será na ambiguidade textual presente na autoficção - a partir de elementos biográficos do autor na tessitura da narrativa ficcional - que surgiram inúmeras discussões em torno do rótulo criado por Doubrovsky. Segundo seu criador, na narrativa autofictícia, a matéria com a qual o romancista irá se valer é de fundo autoral e as estratégias da narrativa, por sua vez, são ficcionais. Contudo, temos constatado estudos divergentes a esse respeito oriundos de críticos tanto franceses (COLLONA, 2004); (GASPARINI, 2008; 2016) quanto brasileiros (FAEDRICH, 2014; 2016); (KLINGER, 2008; 2012). De comum acordo, todas as reflexões desses estudiosos apontam para o fato de que as práticas autoficcionais têm algumas especificidades que não se restringem, apenas, à indissociabilidade entre biografia e ficção.

Doubrovsky, em um primeiro momento, chamou a atenção do leitor para a configuração do enredo de sua autoficção que trataria de "fatos estritamente reais", definição, essa, que o levaria a redefini-la posteriormente. Na quarta edição de sua obra Fils (1977) - título, esse, que em língua portuguesa por ser traduzido como "filhos" ou "fios" - o autor afirma: 
Autobiografia? Não. É um privilégio reservado aos importantes deste mundo, no crepúsculo de suas vidas, e em um belo estilo. Ficção de acontecimentos e de fatos estritamente reais; se se quiser, autoficção, por ter confiado a linguagem de uma aventura à aventura da linguagem, fora da sabedoria e fora da sintaxe do romance, tradicional ou novo. Encontro, fios de palavras, aliterações, assonâncias, dissonâncias, escrita de antes ou de depois da literatura, concreta, como se diz em música, ou ainda, autoficção pacientemente onanista, que espera agora compartilhar seu prazer $^{1}$. (1977, tradução nossa)

Entendida como uma "ficção de acontecimentos reais" e escrita por meio de encontros de "fios" de linguagem especular, esse tipo de texto chamou a atenção da crítica literária pelo fato da inserção performática do autor como personagem do romance, sem máscaras como era feito no romance autobiográfico. Nos estudos de Klinger (2008), por exemplo, o texto autofictício seria fruto de questões paradoxais do final do século $X X$, sobretudo no que diz respeito à crítica estruturalista do sujeito e, consequentemente, da crítica filosófica da representação. Sendo a autoficção um conceito específico da narrativa

1 «Autobiographie? Non. C'est um privilège réservé aux importants de ce monde au soir de leur vie et dans um beau style. Fiction d'évenements et de faits strictement réels; si l'on veut autofiction, d'avoir confié le langage d'une aventure à l'aventure du langage, hors sagesse et hors syntaxe du roman, traditionnel ou nouveau. Rencontres, fils des mots, allitérations, assonances, dissonances, écriture d'avant ou du d'après littérature, concrète, comme on dit en musique. Ou encore, autofiction, patiemment onaniste, qui èspere faire maintemant partager son plaisir» 
contemporânea, Klinger entende que a prática autofictícia está vinculada tanto à teoria de performance do gênero cuja fonte se encontra na obra de Judith Butler, na qual a subjetividade é pensada por meio da "desnaturalização do eu" - bem como do diálogo com a arte cênica da performance. A autoficção resultaria, então, “[...] do desejo narcisista de falar de si e o reconhecimento da impossibilidade de exprimir uma 'verdade' na escrita" (KLINGER, 2008, p. 18-19). E é sob o prisma da performance, do jogo, da ambiguidade intencional que nos valemos para a leitura de narrativas autofictícias que, também, podem ser lidas como versões pós-modernas da autobiografia. Nesse sentido,

[...] é a partir da crítica à noção de representação e de sujeito que se pode formular um conceito de autoficção que seja específico da literatura contemporânea. 0 sujeito que "retorna" nessa nova prática de escritura em primeira pessoa não é mais aquele que sustenta a autobiografia: a linearidade da trajetória da vida estoura em benefício de uma rede de possíveis ficcionais. Não se trata de afirmar que o sujeito é uma ficção ou um efeito de linguagem, como sugere Barthes, mas que a ficção abre um espaço de exploração que excede o sujeito biográfico. (KLINGER, 2008, p. 22) 
$\mathrm{Na}$ narrativa autobiográfica, o chamado "pacto" teorizado por Philippe Lejeune (2014) se torna condição sine qua non para que o leitor leia o texto como um relato da vida do autor. A autoficção quebra esse pacto autobiográfico com o leitor, tendo em vista que essa última prática narrativa está mais interessada em apresentar um "desejo de escritura", no sentido teorizado por Barthes (2004; 2010), do que propriamente a concatenação de fatos vivenciados pelo eu. Apesar de haver alguns casos nos quais há a identificação onomástica entre autor, narrador e protagonista, a autoficção ironiza esse mesmo pacto, transformando a figura empírica do autor na peçachave do jogo textual. Segundo Vincent Colonna (1989), em L'autofiction. Essai sur la fictionnalisation de soi en littérature, na autoficção, apesar de o escritor ser o foco central do enredo, a inserção do eu é transfigurada, sobretudo, por meio do descentramento do sujeito e por uma existência irreal2: "o duplo projetado torna-se um personagem fora da norma, um puro herói de ficção, do qual ninguém teria a ideia de tirar uma imagem do autor ${ }^{3 \prime}$ (apud GASPARINI, 2008, p. 258, tradução nossa).

2 Muito já se discutiu sobre a posição de Colonna, cuja tese foi orientada por Gérard Genette. No fim, sabe-se que eles falam de outra prática, diferente da autoficção doubrovskiana.

3 «Le double projeté devient un personnage hors norme, un pur héros de fiction, dont il ne viendrait à personne l'idée d'en tier une image de l'auteur». 
Tendo como foco da escrita os aspectos autobiográficos do autor, a autoficção traz o problema da representação do sujeito e da sua relação com a escrita enquanto forma e experiência. Foucault (2006), em O que é um autor?, por exemplo, já apontava para a menorização da entidade autoral para fazer surgir, então, "o ser da linguagem" que apaga a visibilidade daquele que fala. Alinhada ao pensamento foucaultiano, a prática autofictícia engloba escolhas e, por sua vez, apresenta perdas e ausências por meio de uma escrita especular, fragmentada e metafictícia na qual faz surgir a figura do "autor enquanto gesto" (AGAMBEN, 2007). O movimento constituinte da autoficção é o inverso daquele apresentado tanto pela autobiografia quanto pelo romance autobiográfico: por se firmar no presente da narração, a autoficção cria a ilusão de vivência momentânea do autor/narrador e não se detém à reconstituição linear de fatos passados ${ }^{4}$. Sendo a lógica texto $\rightarrow$ vida, trata-se mais de uma ficcionalização de si, ou seja, uma duplicidade do eu encenado na escrita que torna a figura do autor um "scriptor", na acepção barthesiana do termo. Na autoficção, "[...] um bom escritor pode chamar a atenção para a sua biografia através do texto ficcional, entretanto, é o texto literário que se destaca em primeiro

4 Esse movimento também foi discutido por Faedrich (2014). 
plano. Os biografemas estão ali funcionando como estratégia literária de ficcionalização de si" (FAEDRICH, 2014, p. 23).

Essa escrita pode estar, diferente da autobiografia, carregada de incertezas, contradições, indefinições e, sobretudo, lacunas que o leitor deverá suprir no ato da leitura. Logo,

a autoficção estaria, então, situada no meio do caminho entre a autobiografia e o romance autobiográfico. Se, hipoteticamente, considerarmos que o romance autobiográfico mistura os signos da autobiografia e do romance em partes iguais, podemos pensar na autoficção como um coquetel constituído por três doses de autobiografia por uma de um romance. Ao contrário do que o nome sugere, e como Doubrovsky repete, estaria mais próximo da autobiografia do que do romance autobiográfico ${ }^{5}$. (GASPARINI, 2008, p. 300301, tradução nossa)

Contrariando a perspectiva pioneira de Doubrovsky, Colonna sustenta que o duplo projetado na autoficção é um puro herói de ficção. Nessa percepção, tira-se a imagem do autor apresentada em Fils, rompendo, então, a ideia de

5 «L'autofiction se situerait donc à mi-chemin de l'autobiographie et du roman autobiographique. Si, par hypothèse, nous considérons que le roman autobiographique mélange à parts égales les signes d'autobiographie et de roman, nous pouvons nous reprénsenter l'autofiction comme un cocktail comprenant trois doses d'autobiographie pour une de roman. Contrairement à ce que son nom sugere, et conformément à ce que répète Doubrovsky, elle se situerait plus près de l'autobiographie que le roman autobiographique.» 
ambiguidade e de indecidibilidade característica do gênero. Logo, entendemos ser mais coerente lermos os textos autoficcionais seguindo alguns dos preceitos de Doubrovsky que foram revistos e ampliados por estudiosos da narrativa brasileira contemporânea, tais como os realizados por Klinger e Faedrich ${ }^{6}$. Em suas investigações, ambas as críticas brasileiras reafirmam como característica da escrita autoficcional a presença da ambiguidade na construção desse tipo de narrativa associada a outras questões. De maneira didática, Faedrich (2016) apresenta uma proposta de "pacto autoficcional" a ser estabelecido com entre texto e leitor. Logo, o contrato de leitura deve-se partir do entendimento de que a autoficção apresenta

[...] uma prática literária contemporânea de ficcionalização de si, em que o autor estabelece um pacto ambíguo com o leitor, ao eliminar a linha divisória entre fato/ficção, verdade/mentira, real/imaginário, vida/ obra, etc; o tempo presente da narrativa e o modo composicional da autoficção, que é caracterizado pela fragmentação, uma vez que o autor não pretende dar conta da história linear e total de sua vida; o movimento da autoficção, que é da obra de arte para a vida - e não da vida para a obra, como na autobiografia -, potencializando o texto enquanto linguagem criadora;

6 Há outros pesquisadores que também se ocuparam das especificidades dos textos autoficcionais na literatura brasileira contemporânea. Aqui, nos serviremos das reflexões de Faedrich e de Klinger. 
identidade onomástica entre autor, narrador e protagonista, que pode ser explícita ou implícita, desde que exista o jogo da contradição, criado intencionalmente pelo autor no próprio livro. E, por fim, a palavra-chave que marca a autoficção como um gênero híbrido: a indecidibilidade. (FAEDRICH, 2016, p. 44-45)

Embora a criação desse neologismo seja posterior ao fenômeno propriamente dito, vários ficcionistas francófonos começaram a rotular seus textos como autoficções. No Brasil, o surgimento dessas narrativas que trazem para o bojo da escrita romanesca a ficcionalização do autor como protagonista da trama se consolidou a partir dos anos 1990. A título de ilustração, podemos citar várias obras autoficcionais que, seguindo a esteira de Doubrovsky, se destacam no cenário da narrativa brasileira contemporânea7: Quase memória: quase romance (1995), de Carlos Heitor Cony; Nove noites (2002), de Bernardo Carvalho; A chave de casa (2007), de Tatiana Salem Levy; O filho eterno (2007), de Cristóvão Tezza; O gosto do apfelstrudel (2010), de Gustavo Bernardo; O diário da queda (2011), de Michel Laub; Divórcio (2013), de Ricardo Lísias; Machado (2016), de Silviano Santiago, dentre várias outras narrativas. A partir

7 Faedrich (2014) apresenta um estudo detalhado sobre as várias formas de autoficções brasileiras. Os romances que apontamos aqui apenas são um demonstrativo dentro de um universo de várias outras obras que foram publicadas até 2021 . 
do embaralhamento entre vida e ficção, os romancistas citados acima criaram textos situados no "entre-lugar" das fronteiras e dos discursos, para utilizarmos a expressão de Santiago (2002). São narrativas que apresentam um "desejo" autobiográfico, mas devem ser lidas como ficcionais. Elas jogam com os limites da escrita, valendose da fragmentação, de digressões e, principalmente, da metaficção como estratégias autofictícias. A linguagem, elemento motriz por meio da qual o escritor cria uma "aventura" e se ficcionaliza, segundo Gasparini (2008), também pode ser vista e/ou lida sob a óptica do campo expandido (KRAUSS, 2007), se pensarmos nas apropriações de discursos de outros campos do saber presentes do texto autoficcional. Além desses aspectos, a autoficção performática, no seu ímpeto fragmentário, inconcluso e ambíguo, vale-se de uma escrita repleta de ausências e de perdas - ao se basear na escolha de fragmentos de ordem biográfica e memorialística - na tentativa desse mesmo eu se materializar, inscrevendo-se no presente da narração.

Dentre essas ficções, há uma que trabalha, em especial, com uma escrita marcada por ausências e, também, por perdas em diferentes instâncias, seja tanto na estrutura do texto - no emprego de vozes narrativas distintas - quanto 
dos fatos narrados que estão relacionados, sobretudo, ao sofrimento, à dor e à morte. Trata-se do romance $A$ chave de casa, publicado em 2007, da escritora Tatiana Salem Levy, cuja narrativa é fruto de sua tese de doutorado. $O$ enredo se serve de memórias da autora e de fatos marcantes de sua vida, muito embora, em nenhum momento do enredo, há a menção ao nome de Tatiana Salem Levy. Nessa autoficção, há uma tentativa de narrar eventualidades, traumas, dores, perdas e principalmente incertezas da narradora - não identificada - em uma escrita fragmentada, ambígua e digressiva. A forma como o romance é arquitetado revela lacunas que os leitores terão de suprir no ato da leitura: constantes anacronias narrativas (inversões temporais) que, na acepção de Genette (1995, p. 33), são diferentes formas de discordância entre a ordem da história e da ordem da narrativa. A instância narrativa, de forma proposital, utilizase de constantes analepses (retornos ao passado, flashbacks) e prolepses (adiantamento de fatos), no intuito de marcar a não precisão e a impossibilidade de se narrar eventos de forma linear e cronológica. Há a recusa em registrar fatos ou eventualidades que descrevam uma tentativa de reconstituição da vida passada: pelo contrário, veremos, por meio dos trechos da obra, que o ato da escrita momentânea registrados no presente da ação servirá à narradora- 
protagonista como uma forma de libertação do martírio ao qual ela tem enfrentado.

\section{A VOZ NARRATIVA PERFORMÁTICA EM A CHAVE DE CASA}

N'A chave de casa, a ausência de certos elementos estruturais da narrativa (nome da narradora, de certos personagens e a não precisão de certos ambientes e contextos) bem como de aspectos que indiquem partes do texto ficcional - não há menção a capítulos, datas ou marcas de cronótopo - permeiam por toda a trama que, ainda, é narrada por meio de fragmentos. Tratamse, na sua grande maioria, de trechos recriados pela voz narrativa de forma performática, uma vez que ela articula lembranças de situações e pessoas no momento presente da escrita em uma tentativa de se autoanalisar no texto ficcional. Contudo, a focalização interna fixa - presente nos momentos nos quais a narradora revela suas incertezas, dilemas e dores ao ter que recontar uma história que não Ihe pertence - torna-se variável e múltipla. O olhar, que até então era fixo, filia-se às dores de outros sujeitos que vão surgindo em seus discursos entrecruzados.

Nessa autoficção, a escolha intencional de Levy por uma instância narrativa autodiegética revela a capacidade dessa voz - a partir de seu lugar de fala - em mobilizar núcleos 
distintos do enredo, interligando-os por meio de focalizações que se expandem. Lapsos de memórias e fragmentos de elementos biográficos são representados por meio de olhares e de épocas que são absorvidas pela narradora. Tendo como suporte a categorização apresentada de Genette (1995), segundo o qual a narrativa é uma sucessão de eventos que se organizam discursivamente nos tempos da história (o que é contado), do discurso (como a história é contada) e da narração (momento em que o narrador está contando a história), examinaremos as especificidades da instância narrativa autodiegética, ou seja, em primeira pessoa que, por vezes, se apresenta por meio de focalizações tanto interna fixa quanto variável e/ou múltipla. Veremos que tais focalizações tem um intuito específico nessa obra: a narradora-protagonista, em um exercício exegético de vasculhar elementos do passado de seus familiares, acabada absorvendo as subjetividades e histórias de vidas desses sujeitos. Logo, sua identidade torna-se descentrada (HALL, 2006) e sua visão sobre os fatos passa a ser variável e múltipla, a partir do momento em que a voz narrativa se apropria das cosmovisões de seus familiares. Essa expansão de focalizações da narradora se manifesta, principalmente, quando a ela conta a história de vida de seu avô - por meio de uma focalização onisciente e, também, em momentos de 
construção de fluxos de consciência - além dos constantes diálogos com a voz materna da narradora, que aparece no enredo por meio de uma escrita endereçada por colchetes [ ], nos quais nota-se o uso pronominal do "você": "[Você nunca pensa em coisas boas? Não tem sonhos?] [...] [E o que é?] Meu sonho, mãe, é escrever. [Escrever?] É, tenho esse sonho impossível: escrever escrever escrever" (LEVY, 2014, p. 107).

No primeiro contato com o romance, o leitor tem a impressão - a partir da leitura do título do livro e da análise dos elementos imagéticos da capa, ao destacar uma espécie de tapete que remete ao artesanato e à cultura turca, - de que a narrativa irá engendrar pelo universo da história de uma dinastia, revisitando arquivos e documentos históricos. Contudo, o que se verifica, desde o primeiro excerto, é uma escrita voltada ao tempo presente do discurso. As ambiguidades, as dúvidas, incertezas e os fragmentos de memórias relacionadas à herança judaica da família da narradora ${ }^{8}$ se instauram desde a primeira linha: "Escrevo com as mãos atadas. Na concretude imóvel do meu quarto, de onde não saio há longo tempo. Escrevo sem poder escrever e, por isso, escrevo" (LEVY, 2014, p.

8 Sobre a presença da herança judaica na narrativa de Levy, ver o estudo de Eurídice Figueiredo (2013) "A herança judaica e a autoficção em Tatiana Salem Levy". 
9). Deparamo-nos, então, com uma narradora em conflito consigo mesma, apresentando-se inconformada com a situação atual de sua vida. Ela se encontra imobilizada em seu quarto e, metaforicamente, entrevada à uma cadeira de rodas. Nesse primeiro contato com o leitor, a instância narrativa já anuncia o problema que a consome: o peso de toda uma geração de familiares que necessitam que sua história seja narrada/revista/explicada aos leitores. Mas as palavras escapam à pena da narradora. $\mathrm{O}$ trabalho da escrita fictícia, desde a primeira menção até a última inscrição no enredo, dá sentido à vida da narradora e a mantém viva. Eis o trecho inicial do romance a que nos referimos:

Escrevo com as mãos atadas. Na concretude imóvel do meu quarto, de onde não saio há longo tempo. Escrevo sem poder escrever e, por isso escrevo. De resto, não saberia o que fazer com este corpo que desde a sua chegada ao mundo não consegue sair do lugar. Porque eu já nasci velha, numa cadeira de rodas, com as pernas enguiçadas, os braços ressequidos. Nasci com o cheiro de terra húmida, o bafo de tempos antigos sobre o meu dorso. Falo de um peso que carrego nas costas, um peso que me endurece os ombros e me torce o pescoço, que me deixa dias a fio - às vezes um, dois meses - com a cabeça na mesma posição. Um peso que não é de todo meu, pois já nasci com ele, como se toda vez que digo "eu" estivesse dizendo "nós". Falo sempre 
na companhia desse sopro que me segue desde o primeiro dia.

Um sopro me paralisa. Uma espécie de fardo. Pesado. Mais do que isso: bruto, acimentado, capaz de me tirar todas as possibilidades de movimento, amarrando as articulações uma à outra, colando todos os espaços vazios do meu corpo. Não que eu seja uma pessoa triste. Não se trata de ser ou não feliz, mas de uma herança que trago comigo e da qual quero me livrar. Nem que para isso tenha de correr riscos sem medida, nem que para isso tenha de me desfazer de tudo o que construí até hoje, de tudo o que acreditei ser a minha vida. Estou num ponto em que preciso mudar a direção do barco, ou então serei capturada pelo olhar de Medusa e me tornarei pedra, lançada ao mar.

No entanto, as palavras ainda me escapam, a história ainda não existe. Enquanto os músculos pesam e permanecem, o sentido se esvai. Quem sabe aos poucos, quando conseguir dar os primeiros passos, quando conseguir me libertar do fardo, não consiga também dar nome às coisas? $\mathrm{E}$ por isso, só por isso escrevo. (LEVY, 2014, p. 9-10)

A indisposição em narrar histórias com as quais a narradora não conhece e não se sente à vontade tem lhe causado várias consequências físicas e psíquicas. O leitor, por sua vez, ao se apoiar em pistas biográficas de Tatiana Salem Levy, irá entender que há uma correspondência sutil entre autora/narradora/protagonista, uma vez que em 
vários momentos do texto há indícios no quais fica nítido o jogo ambíguo e indissociável entre biografia e ficção mediado pela narradora: "Nasci no exílio. Em Portugal, de onde séculos antes a minha família havia sido expulsa por ser judia. Em Portugal, que acolheu meus pais, expulsos do Brasil por serem comunistas" (LEVY, 2014, p. 25).

Neta de judeus turcos, nascida em Lisboa e emigrada ao Brasil com nove meses de idade, Levy utilizou subsídios de suas vivências, de seus pais e avós para construir os eixos narrativos do romance $A$ chave de casa. $O$ tema da narrativa, por exemplo, remete a uma história da época da inquisição, na qual os judeus foram expulsos da península ibérica e seguiram, em sua grande maioria, para a Turquia, para a Holanda e para o norte da África. Tais povos acreditavam que um dia poderiam retornar às suas casas e, por tal razão, portaram consigo as chaves de suas residências na esperança de que um dia pudessem retornar. Essa chave emblemática e simbólica era repassada aos seus descendentes. A autora, então, ao ter ouvido a história de um tio avô - que havia saído da Turquia e tinha ido a Portugal, onde conseguiu cidadania, também possuía a chave de sua casa - a utilizou como um dos pilares para estruturar o seu enredo. Essa investigação de cunho histórico seria, a princípio, o tema do romance de 
Levy. Contudo, no processo de escrita, o que deveria ser um romance histórico acabou se tornando uma narrativa multifacetada, digressiva e metaficcional, desdobrando-se em relatos imprecisos e que geram mais dúvidas do que certezas nos leitores:

Para escrever esta história, tenho que sair de onde estou, fazer uma longa viagem por lugares que não conheço, terras que onde nunca pisei. Uma viagem de volta, ainda que eu não tenha saído de lugar algum. Não sei se conseguirei realizá-la, se algum dia sairei do meu próprio quarto, mas a urgência existe. Meu corpo já não suporta tanto peso, torneime um casulo pétreo. Tenho o rosto abatido, orelhas muito mais velhas do que eu. Minhas bochechas pendem, ouvindo o chamado da terra. Meus dentes mal conseguem mastigar, como se a gravidade agisse com mais intensidade em mim, puxando suas vezes meu corpo para baixo.

Não tenho a mais ínfima ideia do que me aguarda nesse caminho que escolhi. Da mesma forma, não sei se faço a coisa certa. Muito menos se existe alguma lógica, alguma explicação admissível para essa empreitada. Mas ando em busca de um sentido, um nome, um corpo. E por isso farei essa viagem de volta, para ver se não os esqueci perdidos por aí, em algum lugar ignoto.

Sem me levantar, pego a caixinha na mesa de cabeceira. Dentro dela, em meio a pó, bilhetes velhos, moedas e brincos, descansa a chave que ganhei do meu avô. Tome, ele 
disse, essa é a chave da casa onde morei na Turquia. Olhei-o com expressão de desentendimento. Agora, deitada na cama com a chave nas mãos, sozinha, continuo sem entender. $\mathrm{E}$ o que vou fazer com ela? Você é quem sabe, ele respondeu, como se não tivesse nada a ver com isso. As pessoas vão ficando velhas e, com medo da morte, passam aos outros aquilo que deveriam ter feito mas, por motivos diversos, não fizeram.

E agora cabe a mim inventar que destino dar a essa chave, se não quiser passá-la a diante. (LEVY, 2014, p. 12-13)

Tanto nesse excerto quanto no anterior, nota-se que estruturação do romance de Levy segue a estratégia digressiva entendida como "horror à linha reta" (PAES, 1998) presente na narrativa Vida e opiniões do cavalheiro Tristram Shandy (1998), de Laurence Sterne, e que foi adotado por Machado de Assis e por vários outros ficcionistas modernistas e contemporâneos. A todo momento, a instância narrativa tentar escrever a suposta história de sua família e, logo, de si mesma, mas se vê impossibilitada por motivos que fogem à motivação inicial imposta à ela:

[...] com o grão de energia que ainda me resta, pego a máquina de escrever que me esmaga o ventre e repouso-a no chão. Em seguida, seguro as duas pontas do lençol enroscado ao pé da cama e puxo-o para cima de mim, cobrindo-me inteiramente, fosse um sudário. (LEVY, 2014, p. 80) 
Quase em seu leito de morte, a narradora-protagonista encontra no exercício de escrita uma possibilidade de seguir sua vida. Contudo, os infortúnios ao seu redor, somados às histórias entrelaçadas à sua a paralisam e a impossibilitam de narrar os fatos. Ao lado de sua tentativa de escrita, há outras três narrativas paralelas que a narradora-protagonista as concatena em sua escrita autoanalítica. Ao todo, há quatro eixos principais no enredo. São eles: 1) a história da narradora-protagonista - não identificada, embora apresente semelhanças com dados autorais de Tatiana Salem Levy -; 2) a história de uma relação amorosa conturbada da narradora com um homem violento; 3) a história de seu avô, que saiu da Turquia ainda jovem e veio ao Brasil para ter oportunidades de emprego e constituir família aqui; 4) e a história de sofrimento da mãe (exilada à época da ditadura civil-militar, submetida a sessões de tortura e ainda contraiu um câncer que a levou à morte) que aparece no romance, como vimos, por meio de diálogos com a narradora. Nas constantes conversas com o espírito da mãe, a memória da narradora articula momentos nos quais essa consciência materna funciona, dentre outras coisas, como uma espécie de coautoria do texto que deverá ser escrito. Ambas discutem, dentre outras coisas, como a narrativa deve ser escrita, sem que haja pudores de transgressão de limites, uma vez 
que a história a ser contada não se restringia, somente, à identidade da narradora-protagonista, mas sim, de toda uma geração. No trecho abaixo, lemos:

[A história não é só dele, a vida nunca é de uma única pessoa. Se lhe entregou a chave, é porque acredita que ela faça parte da sua história. Você conhece o meu pai, nada para ele é sem razão. Ele poderia ter dado essa chave a mima ou a um dos meus irmãos, mas nunca o fez. Não conheci a Turquia e agora já não posso mais. Poucas vezes ouvi as histórias de sua vinda. Não estou querendo dizer que haja um destino, uma missão que só você possa cumprir. Você sabe, poucas pessoas são tão céticas quanto eu. Mas tampouco acho que possamos estar por aí a refutar o que nos oferecem. Quanto tempo faz que você está nessa cama? Talvez essa seja uma boa maneira de se mexer, sair do encarceramento desse quarto e ir a um país desconhecido. Acredite nessa história que seu avô lhe oferece, vá em busca de sua casa e tente abrir a porta. Reconte a história do seu avô, reconte a minha também, conteas você mesma. Não tenha medo de nos trair. Tome essa possibilidade como uma chance de sair do lodo onde se soterrou, mesmo que não dê em nada, não ache casa alguma, não reencontre a parte da família que lá ficou, não importa. Ao menos estará conhecendo novos - e tão antigos - ares.] (LEVY, 2014, p. 18)

A autorreflexividade presente na escrita ficcional, configurando-a como uma metaficção, ou seja, uma 
construção narrativa que se ocupa dos meandros e do engenho ficcional como matéria narrada, faz-se presente constante na fala da narradora que se vale das memórias de seu avô, de sua mãe e de si mesma. Entrelaçada a esses quatro eixos narrativos, o texto torna evidente a busca pela própria realidade narrativa da qual Levy trata, em seu estudo teórico-crítico A experiência do fora: Blanchot, Foucault e Deleuze (2011). Nesse estudo, a romancista se ocupa em examinar como tais pensadores pós-estruturalistas tratam da "experiência do fora", reflexão, essa, que promove uma mudança paradigmática no entendimento da noção de realismo. Estar fora seria "sair da dialética, repensar as noções de sujeito e de história, e com elas as de autor, verdade e origem, são gestos fundamentais quando se quer conceber uma nova maneira de pensar" (LEVY, 2011, p. 25). A escrita em $A$ chave de casa se apresenta de forma desdobrada, se levarmos em consideração que ela questiona o logos clássico e propõe, como quer Deleuze (2011), puro devir, o vir a ser por meio de "acontecimentos puros" e "simultâneos": "[...] o puro devir, o ilimitado, é a matéria do simulacro, na medida em que se furta à ação da ideia, na medida em que se contesta ao mesmo tempo tanto o modelo como a cópia" (DELEUZE, 2011, p. 2). 
Os núcleos narrativos presentes na narrativa de Levy confirmam os dizeres de Deleuze, no sentido da criação de acontecimentos puros, e de Blanchot $(1987$; 1997) segundo o qual o grande paradoxo da arte reside na sua irrealização: "é preciso negar o real para se construir a (ir)realidade fictícia" (LEVY, 2011, p. 23). Para a própria autora,

essa realização da obra - sua possibilidade - tem como essência a sua impossibilidade. [...] Tudo se passa como se estivéssemos em presença da verdade, mas essa presença não chega a acontecer de fato. É justamente essa impossibilidade essencial que determina a possibilidade da literatura. É porque se projeta para a não linguagem que a linguagem literária se torna real. Essa não linguagem funciona como um aviso à linguagem de sua insuficiência: a literatura tenta permanentemente o suicídio, mas não pode alcançá-lo. A arte procura sempre sua própria destruição, a negação de si mesma, mas é nesse movimento que ela determina por se fundar, garantindo sua eternidade. (LEVY, 2011, p. 22)

A todo momento, a narradora-protagonista busca evidenciar o caráter autorreflexivo de sua escrita por meio de questionamentos do próprio fazer literário e, também, se o que ela está narrando, no presente da escrita autofictícia, tem sentido. É comum nos depararmos com relatos ambíguos, conflituosos, paradoxais e até, em 
certa medida, repetitivos. Sua saga em busca de si mesma começaria em uma viagem rumo à Istambul, na Turquia. Chegando lá, ela não se identifica com o lugar e segue rumo à Esmirna, cidade na qual estava a casa que seu avô deixara. Entretanto, a narração polemiza essa própria viagem, chegando ao ponto de dizer que tal aventura em busca de sua identidade, bem como de seus familiares, não deveria nem estar no roteiro em sua escrita:

Essa viagem é uma mentira: nunca saí da minha cama fétida. Meu corpo apodrece a cada dia, as pústulas corroem minha própria carne e em pouco tempo serei apenas osso. Tenho as pernas em chagas purulentas, a carne viva. Como poderia fazer essa viagem? Não tenho articulações, tenho ossos colados uns aos outros. Só poderia sair da cama carregada por alguém, mas quem iria levar nos braços corpo tão repugnante? E para que? Tenho em mim o silencio e a solidão de uma família inteira, de gerações e gerações. Como se toda a alegria que cada um viveu fosse se desprendendo leve no ar e ficasse apenas a tristeza. E como se essa tristeza fosse se acumulando, se acumulando até chegar em mim. Quando nasci, meus pais me olharam e desde então souberam que eu era a tristeza e a solidão. Que depois de mim não haveria nada, porque depois da tristeza e da solidão não há nada. Desde pequena, quando alguém me olha, vejo o medo lhe tomar o rosto, porque desde que vim ao mundo sou velha e carrego a morte estampada nos olhos. 
Nunca saí do lugar, nunca viajei, não conheço senão a escuridão do meu quarto. A chave que meu avô me deu descansa ainda ao meu lado, estirada na cama como parte do meu corpo podre. Estamos, as duas com uma cor de bronze gasto, empoeiradas. Somos feito uma, tão enferrujadas que, nas mãos de alguém, seríamos apenas pó, carne e metal despedaçados. (LEVY, 2014, p. 105-106)

As contradições presentes na mimese do processo (HUTCHEON, 1984) são estratégias autorreflexivas que põem em xeque a referencialidade externa ao texto, o que reforça o caráter autoconsciente da autoficção. As dúvidas e, também, reafirmações sobre os motivos que levam a narradora-protagonista a escrever são recorrentes. Os excertos transcritos a seguir, tanto da página 61 quanto da página 133, se valem de uma dicção metaficcional. Na primeira passagem, a dor relacionada à morte da mãe dá sentido à imobilidade do corpo da narradora. Já na segunda transcrição, é a conflituosa relação com um homem inominável que a faz "inventar" histórias. Nota-se que ambos os trechos se configuram como "capítulos" distintos da obra, muito embora eles são repetitivos em vários aspectos:

Conto (crio) essa história dos meus antepassados, essa história das migrações e suas perdas, essa história da chave de casa, da esperança de retornar ao lugar de onde eles saíram, mas nós duas (só nós 
duas) sabemos ser outro o motivo da minha paralisia. Conto (crio) essa história para dar algum sentido à imobilidade, para dar uma resposta ao mundo e, de alguma forma, a mim mesma, mas nós duas (só nós duas) conhecemos a verdade. Eu não nasci assim. Não nasci em nenhuma cadeira de rodas, não nasci velha. Nenhum passado veio me assoprar nos ombros. Eu fiquei assim. Fui perdendo a mobilidade depois que você se foi. Depois que conheci a morte e ela me encarou com seus olhos de pedra. Foi a morte (a sua) que me tirou, um a um, os movimentos do corpo. Que me deixou paralisada nessa cama fétida de onde hoje não consigo sair. (LEVY, 2014, p. 61)

A ideia de escrita como "criação", "invenção" e descompromissada com a suposta "realidade" histórica da família da narradora é reafirmada em um jogo repetitivo de ideias que configura a autoficção como um texto não linear, logo, sem uma conclusão plausível:

Conto (crio) esta história dos meus antepassados, essa história das imigrações e suas perdas, essa história da chave de casa, da esperança de retornar ao lugar de onde eles saíram, mas só dois (só nós dois) sabemos ser outro o motivo da paralisia. Conto (crio) essa história para dar algum sentido à imobilidade, para dar uma resposta ao mundo e, de alguma forma, a mim mesma, mas nós dois (só nós dois) conhecemos a verdade. Eu não nasci assim. Não nasci numa cadeira de rodas, não nasci velha. Nenhum passado veio me assoprar os ombros. Eu 
fiquei assim. Fui perdendo a mobilidade depois que o conheci. Depois que o amei: depois que conheci a loucura através do nosso amor, o nosso. Foi o amor (excedido) que me tirou, um a um, os movimentos do corpo. Que me deixou paralisada nessa cama fétida de onde hoje não consigo sair. (LEVY, 2014, p. 133)

A narradora-protagonista reafirma por meio de diferentes fragmentos que a dor é uma experiência física, assim como o ato da escrita que a mantém viva. "Criar" histórias dá sentido à atual situação na qual se encontra a narradora, além, como já observado, evidencia o caráter autofictício da narrativa. Além disso, a insistência em fazer o leitor acreditar que existe uma "verdade" textual nas diversas ausências presentes nos comentários autoconscientes endossam o pensamento de Blanchot (2013) como uma obra que se arruína e se constitui por meio de um

$$
\begin{aligned}
& \text { movimento que de algum modo a anula } \\
& \text { sempre, levando-a de volta à ausência de } \\
& \text { obra, mas nunca definitivamente. Oscilação } \\
& \text { inconclusa, eis a obra da modernidade: } \\
& \text { desdobramento. O desdobramento é o que, } \\
& \text { como o neutro, anula o tempo, dissolve a } \\
& \text { história, desbarata a dialética e a verdade, } \\
& \text { abole o sujeito e faz soçobrar uma ordem. } \\
& \text { (PELBART, 1989, p. 177) }
\end{aligned}
$$

Os diversos fragmentos da memória, narrados de forma autoconsciente, reforçam que a escrita é uma experiência 
física, carnal e dolorosa. A dor e o sofrimento da narradora - por não se ver pertencer a um lugar específico e por ter que carregar as mazelas de seus familiares - são somatizadas em seu corpo físico. Em vários momentos da narrativa, ela está a definhar e seu corpo apresenta as chagas de todas a dores sofridas de sua família. Tais aspectos apresentam intertextualidade direta de $A$ chave de casa $\operatorname{com} A$ metamorfose (1997), de Franz Kafka, ao remeter às angústias e ao sofrimento de Grégor Samsa, bem como à Carta ao pai, na qual há o registro dor e ausência da figura paterna. Além disso, não à toa, Levy utiliza, também, como epígrafe do seu romance um poema da Emily Dickinson, cuja semântica ecoará pelas vozes dissonantes de toda a narrativa:

Dizem que o tempo ameniza.

Isto é faltar com a verdade.

Dor real se fortalece

Como os músculos, com a idade.

É um teste no sofrimento

Mas não o debelaria.

Se o tempo fosse remédio

Nenhum mal existiria.

(DICKINSON, apud LEVY, 2014, p. 7)

A dor somatizada no corpo se torna latente ao passo que a narradora-protagonista passa a incorporar a dor dos outros, sobretudo de suas relações sexuais violentas e, também do luto eterno de sua mãe. Por outro lado, 
ela se vê obrigada a escrever porque "nenhuma palavra dói mais do que a ausência da palavra" (LEVY, 2014, p. 139). A ausência, nesse sentido, expande-se para além de estrutura textual da autoficção de Levy e se encontra no próprio substrato da escrita:

A dor está em tudo, espalhada por todos os cantos do planeta, por todos os cantos de nós. Não existe nem mesmo um poro da pele que não carregue dor. Os sentimentos mudam, mas a dor persiste. Em tudo o que experimentei, lá estava ela, de um jeito ou de outro. No amor, na alegria, na tristeza, no sofrimento, no luto, nos sonhos, nunca conheci nada sem dor. Não concordo quando você diz que sou eu que levo as coisas para o lado da dor. Não sou eu, é a vida, mãe, é ela que é assim.

Essa viagem que faço, esse país estranho onde vim parar, tudo isso dói. É bonito, é interessante, é engraçado, mas dói. Essa herança dói. $O$ que trago comigo sem escolha dói. Essa nossa conversa, mãe, também dói. A história do meu avô, a sua história, a tortura, o exílio, tudo dói. E, sobretudo, dói falar de dor. Dói escrever essa história. Cada nova palavra que encontro dói. Escrever, mãe, dói imensamente. Dói tanto quanto é necessário. (LEVY, 2014, p. 147)

A ausência de um eixo narrativo definido confirma a multi-identidade do sujeito contemporâneo descentrado. Em todo o enredo, a voz da narradora-protagonista se 
ampara nos discursos dos outros para se constituir. Ela traz consigo a identidade de sua mãe, de seu avô, de sua herança judaica e de seus relacionamentos amorosos. A metáfora da chave, como símbolo de mudança, passagens, revelações e descobertas é, para si mesma, emblemático:

Não faço outra coisa senão olhar, tocar, observar a chave. Conheço seus detalhes de cor, o tamanho preciso de suas curvas e de sua argola, seu peso, sua cor gasta. Uma chave desse tamanho não deve abrir porta alguma. A essa altura já devem ter mudado, se não a porta, certamente a fechadura. Seria um disparate acreditar que tanto tempo depois a chave da casa permaneceria a mesma. Tenho certeza de que até meu avô é consciente disso, mas também imagino que deva ter uma curiosidade enorme de saber se ainda está lá o que deixou para trás. Que coisa estranha, que coisa esquisita dever ser largar o país, a língua, abandonar a família em direção a algo completamente novo e, sobretudo, incerto.

Ele me contou que o navio onde viajou era descomunal, seu primeiro e único navio. $\mathrm{A}$ embarcação estava abarrotada de pessoas, todas com a mesma esperança que ele: conseguir vida melhor em país diferente. Dos irmãos, foi o primeiro a vir, apenas duas malas na mão e alguns contatos no Brasil. Não tinha mais do que vinte anos quando deixou a Turquia. Tempos depois o irmão mais novo se juntaria a ele. A irmã gêmea faleceria de tuberculose. O irmão mais 
velho casaria e continuaria em Esmirna. A mãe, ele só reencontraria longos anos mais tarde, quando viúva, decidiria se mudar para o Brasil.

Quantas vezes não ouvi essa mesma história? A dor de nunca mais ter visto o pai nem a irmã, de nunca mais ter pisado na terra que primeiro fora sua. A dor de só ter trazido a mãe a tempo de perde-la. De ter visto tanta miséria no navio, tanta miséria na terra que deixara. Quantas vezes?

E agora o que ele quer? Que eu vá atrás de sua história, recuperar seu passado? Por que essa chave, essa missão descabida? (LEVY, 2014, p. 16-17)

A missão árdua de ir em busca de sua família na Turquia torna-se um fado para esse sujeito que não encontra sentido no seu estar-no-mundo. Por meio da voz da narradora, - leitor acompanha uma trajetória feita de zigue-zagues que dá a ilusão de que o texto não avança e que não tem início, nem meio e nem fim. Junto à sua tentativa de escrita em busca de pertencimento e autoconhecimento, a voz narrativa trava conflituosos diálogos com o espectro de sua mãe e rememora momentos de tensão e briga com um homem violento. Sobretudo nos diálogos, a voz materna funciona como o juízo crítico da narradora, corrigindo-a e, ao mesmo tempo, norteando-a como espécie de psicóloga que a reconforta: 
Quase todos os dias há momentos em que faço alguma coisa e logo em seguida penso: não sou eu. Coisas bobas, do cotidiano, somo sorrir, encolher o corpo no sofá para ler o jornal ou segurar a xícara de café com as duas mãos. De repente, no meio do gesto, sou acometida pela sensação de que não sou eu quem está ali. Quando emendo uma migalha na outra, por exemplo, e não consigo parar, tenho a certeza de que é você quem está rindo. [É verdade, somos muito parecidas. Também já tive essa sensação, olhava para você e pensava em como somos iguais]. Mas não é isso, é uma sensação esquisita, uma certeza absoluta de que não sou eu. Nem sempre é você, às vezes é o papai, às vezes o vovô, às vezes nenhum de vocês. As vezes sinto que é alguém que nunca conheci, mas que fala através de mim. Como se meu corpo não fosse apenas meu, e a cada momento eu percebesse essa multiplicidade, a existência de outras pessoas me acompanhando. [Mas isso é apenas uma sensação, não é real. Você é você e ponto final. O resto, querida, são apenas semelhanças que nos fazem lembrar de alguém.] Não, mãe, não vou reduzir o que sinto a essa palavra tão simples: semelhança. Não digo que sejam espíritos, mas semelhança é uma palavra pobre. Talvez não consiga fazê-la acreditar, mas sei que quando meu dorso se curva em forma de gancho não sou apenas eu quem se curva. Eu sei, mãe, mesmo que não encontre palavra certa, que meu corpo não é só de mim. (LEVY, 2014, p. 49-50) 
Ao lado desses diálogos profundamente marcados pela dor da perda de mãe, há uma rememoração de uma tensa relação amorosa. Cenas extremamente eróticas e sexuais são narradas pela protagonista autodiegética com um homem - também não identificado - com o qual se rendem a prazerosos momentos de paixão bem como a momentos de ira, cujas lembranças também revelam medo violência “Entre nós não havia amor. Havia medo" (LEVY, 2014, p. 175). $O$ trecho a seguir ilustra esses embates:

Quando acordei, estava molhada, a sua mão por debaixo da minha saia, a calcinha afastada para o lado. Estávamos rodando a Itália de carro, do norte ao sul. Acordei como quem acorda de um sonho erótico, mas era a sua mão, eram os seus dedos curiosos. O carro em alta velocidade, e você com apenas uma das mãos no volante, mirando o horizonte. Fingi continuar dormindo. Controlei qualquer vontade de me mexer, afastar mais as pernas ou me afundar no banco. Meu corpo, aparentemente imóvel, a mil. Será que você desconfiou que eu estava desperta? Seu dedo cada vez mais ligeiro, pensei que não aguentaria continuar inerte. (LEVY, 2014, p. 79)

Tais episódios são entrecortados por registros memorialísticos do avô da narradora, focalizando suas peripécias, amores e sua edificação no Brasil, avô, esse, cuja quinta filha de seu casamento é a mãe da 
narradora-protagonista. Nesses hibridismos de discursos memorialísticos, a suposta viagem da narradora-protagonista é marcada pelos seguintes itinerários: Istambul, cidade de portas - "[...] A cada esquina, deparo-me com uma nova porta que me atrai por motivos diferentes: o tamanho da fechadura, complexidade dos desenhos, cor da madeira, peso, cheiro" (LEVY, 2014, p. 63); Depois, Esmirna. Contudo,

[...] a casa não está mais lá, foi destruída há cerca de quinze ano, mais ainda há outras muito parecidas, construídas na mesma época, no mesmo estilo. Tiro a chave da bolsa, seguro-a, observo-a e penso que já não há mais casa, não tenho motivo continuar a viagem. [...] Fecho a porta do carro e, enquanto caminho até o quarto do hotel, penso que já não tenho o que fazer neste país, que nem sei se um dia tivera. (LEVY, 2014, p. 159-160)

Após ter deixado Esmirna, na suposta viagem em busca da casa e na tentativa de entender-se a si mesma e em dar sentido à história de seus familiares, a narradora chega à Portugal. Sem encontrar algum sentido em terras lusitanas, a instância narrativa resolve voltar ao Brasil: "[...] Vim a Portugal desfazer velhos laços e acabei fazendo novos" (LEVY, 2014, p. 202).

Ao término da saga em busca do autoconhecimento, a narradora-protagonista volta ao ponto inicial de sua 
investigação: no quarto, na cama, imóvel. Em uma espécie de sonho, ela entrega a seu avô a chave da casa, para que, então, ele mesmo possa narrar sua história:

[...] sem me levantar, pego a caixinha na mesa de cabeceira. Dentro dela, em meio a pó, bilhetes velhos, moedas e brincos, descansa a chave. Ele estica o olhar e vê o mesmo que eu. Ele me encara, e já não preciso dizer nada. Pego a chave, assopro a poeira em que está mergulhada e, esticando o braço, alcanço a mão do meu avô. Seguro-a com força, e permanecemos com as mãos coladas, a chave entre nosso suor, selando e separando as nossas histórias. (LEVY, 2014, p. 205)

Chegamos ao término da narrativa com o propósito de confirmar uma das condições para que exista o pacto autoficcional: a impossibilidade de se narrar a vida do autor de forma linear no texto ficcional. Aqui, a narradoraprotagonista, imbuída do papel de articular os vários eixos narrativos, teve papel fundamental em criar ambiguidades intencionais por meio da sobreposição de memórias de sujeitos à sua visão da vida. Por fim, a escrita da ausência construída por meio da narradora de $A$ chave de casa pode ser lida por meio da "multiplicidade" e das "máquinas desejantes, dos objetos parciais e dos fluxos contínuos" (DELEUZE; GUATTARI, 2010, p. 16). Partindo desse descentramento do sujeito contemporâneo incapaz de se 
definir como uma totalidade no sentido cartesiano, sua identidade torna-se fluida e ele passa, então, a incorporar outros eus e vivências de sujeitos.

\section{REFERÊNCIAS}

AGAMBEN, Giorgio. O autor como gesto. In: AGAMBEN, Giorgio.

Profanações. Tradução de Selvino José Assman. São Paulo: Boitempo, p. 55-63, 2007.

BARTHES, Roland. A morte do autor. In: BARTHES, Roland. O rumor da língua. Tradução de Mário Laranjeira. São Paulo: Martins Fontes, p. 57-64, 2004.

BARTHES, Roland. O prazer do texto. Tradução de J. Guinsburg. São Paulo: Perspectiva, 2010.

BARTHES, Roland. S/Z. Tradução de Maria de Santa Cruz e Ana Mafalda Leite. Lisboa: Edições 70, 1999.

BLANCHOT, Maurice. A parte do fogo. Tradução de Ana Maria Scherer. Rio de Janeiro. Rocco, 1997.

BLANCHOT, Maurice. O espaço literário. Tradução de Álvaro Cabral. Rio de Janeiro: Rocco, 1987.

BLANCHOT, Maurice. O livro por vir. Tradução de Leyla Perrone-Moisés. São Paulo: Editora WMF Martins Fontes, 2013.

DOUBROVSKY, Serge. Fils. Paris: Galilée, 1977.

DELEUZE, Gilles. Lógica do sentido. Tradução de Luiz Roberto Salinas Fortes. São Paulo: Perspectiva, 2011.

DELEUZE, Gilles; GUATTARI, Félix. $O$ anti-édipo: capitalismo e esquizofrenia. Tradução de Luiz B. L. Orlandi. São Paulo: Ed. 34, 2010. FAEDRICH, Anna. Autoficção: um percurso teórico. Criação \& Crítica, n. 17, p. 30-46, dezembro de 2016.

FAEDRICH, Anna. Autoficções: do conceito teórico à prática na literatura brasileira contemporânea. 2014. 251f. Tese (Doutorado em Letras) Pontifícia Universidade Católica do Rio Grande do Sul, Porto Alegre, 2014. 
FIGUEIREDO, Eurídice. Herança judaica e autoficção em Tatiana Salem Levy. In: FIGUEIREDO, Eurídice. Mulheres no espelho: autobiografia, ficção, autoficção. Rio de Janeiro: EdUERJ, p. 179-89, 2013.

FOUCAULT, Michel. O que é um autor? Tradução António Fernando Cascais. Veja: Lisboa, 2006.

GASPARINI, Philippe. Autofiction. Une aventure du langage. Paris: Éditions du Seuil, 2008.

GENETTE, Gérard. Discurso da narrativa. Tradução de Fernando Cabral Martins. Lisboa: Vega, 1995.

HALL, Stuart. A identidade cultural na pós-modernidade. Tradução de Tomaz Tadeu da Silva e Guaracira Lopes Louro. Rio de Janeiro: DP\&A, 2006.

HUTCHEON, Linda. Narcissistic narrative: the metafictional paradox. New York: London, Methuen, 1984.

KAFKA, Franz. A metamorfose. Trad. Modesto Carone. São Paulo: Companhia das Letras, 1997.

KAFKA, Franz. Carta ao pai. Tradução de Modesto Carone. São Paulo: Companhia das Letras, 1997.

KLINGER, Diana. Escrita de si como performance. Revista Brasileira de Literatura

Comparada, n. 12, p. 11-30, 2008.

KLINGER, Diana. Escritas de si, escritas do outro: o retorno do autor e a virada etnográfica. Rio de Janeiro: 7 Letras, 2012.

KRAUSS, Rosalind. A escultura em campo ampliado. In: KRAUSS, Rosalind. Caminhos da escultura moderna. Tradução de Julio Fischer. São Paulo: Martins Fontes, 2007.

LEJEUNE, Philippe. O pacto autobiográfico: de Rousseau à internet. Tradução de Jovita Maria Gerheim Noronha e Maria Inês Coimbra Guedes. Belo Horizonte: Editora UFMG, 2014.

LEVY, Tatiana Salem. A chave da casa: experimentos com a herança familiar e literária. 2007. Tese (Doutorado em Letras) - Pontifícia Universidade Católica do Rio de Janeiro, Rio de Janeiro, 2007. 
LEVY, Tatiana Salem. A experiência do fora: Blanchot, Foucault e Deleuze. Rio de Janeiro: Civilização brasileira, 2011.

LEVY, Tatiana Salem. A chave da casa. Rio de Janeiro: Record, 2014.

PAES, José. Sterne ou o horror à linha reta. In: STERNE, Laurence. $A$ vida e as opiniões do cavalheiro Tristram Shandy. Tradução de José Paulo Paes. São Paulo: Companhia das Letras, 1998.

PERBALT, Peter Pál. Da clausura do fora ao fora da clausura: loucura e desrazão. São Paulo: Brasiliense, 1989.

SANTIAGO, Silviano. Nas malhas da letra: ensaios. Rio de Janeiro: Rocco, 2002.

STERNE, Laurence. A vida e as opiniões do cavalheiro Tristram Shandy. Tradução de José Paulo Paes. São Paulo: Companhia das Letras, 1998.

\section{Paulo Alberto da Silva Sales}

Doutor em Estudos Literários (2010-2014), pela Universidade Federal de Goiás, onde desenvolveu o primeiro estágio pós-doutoral (2017-2018). Em 2021, desenvolve segundo estágio pós-doutoral no PPG em Estudos de Literatura da UFF, sob supervisão da Profa Ida Alves e Co-supervisão de Célia Pedrosa.

Docente do Instituto Federal Goiano Campus Hidrolândia, Goiás, Brasil e do Programa de Pós-Graduação em Língua, Literatura e Interculturalidade da Universidade Estadual de Goiás (POSLLI), Campus Cora Coralina, Cidade de Goiás, Goiás, Brasil.

Integrante dos grupos de pesquisa "Estudos sobre a narrativa brasileira contemporânea" e "Estudos da Personagem da Literatura Portuguesa". Lattes: https://lattes.cnpq.br/2235713534521313

E-mail: paulo.alberto@ifgoiano.edu.br

ORCID iD: https://orcid.org/0000-0001-9980-2561 